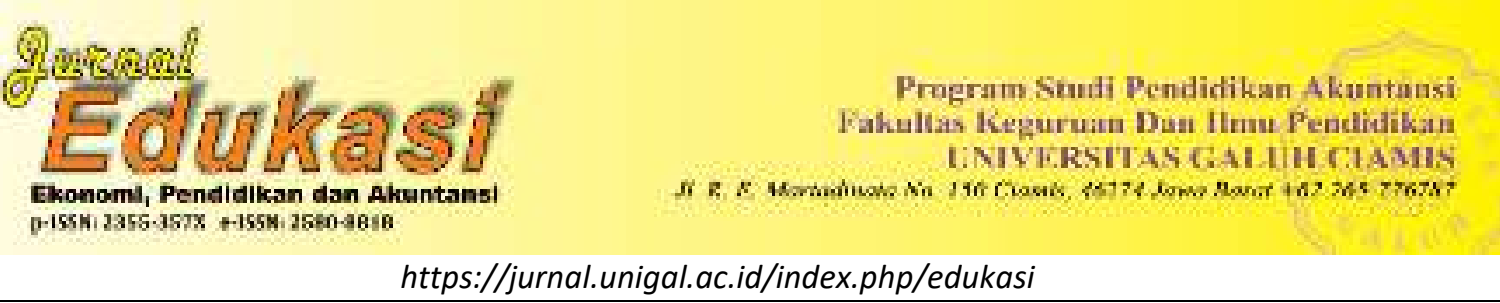

\title{
PERBEDAAN HASIL BELAJAR PESERTA DIDIK YANG MENGGUNAKAN MODEL PEMBELAJARAN THINK PAIRS SHARE (TPS) DENGAN MODEL PEMBELAJARAN VISUALIZATION, AUDITORY, KINESTHETIC (VAK) PADA MATA PELAJARAN AKUNTANSI BIAYA
}

(Studi Eksperimen Kompetensi Dasar Menyusun Laporan Biaya Kelas XI Kompetensi Keahlian Akuntansi Di SMK Hepweti Ciamis)

Oleh:

Dedeh $^{1}$, Sofi Awalia Nurfitriani ${ }^{2}$

Program Studi Pendidikan Akuntansi Universitas Galuh, Indonesia Email:dedeh.akt15@gmail.com ${ }^{1}$,sofiawalianurfitriani.student@unigal.ac.id ${ }^{2}$ Sejarah Artikel: Diterima April 2019, Disetujui Mei 2019, Dipublikasikan Juni 2019

\begin{abstract}
ABSTRAK
Pembelajaran adalah suatu proses untuk menyampaikan materi secara formal kepada peserta didik, selain itu dalam pembelajaran guru harus dapat menciptakan berbagai interaksi dengan peserta didik. Selama ini pembelajaran dikelas selalu berpusat pada guru yang menerangkan dan peserta didik mendengarkan. Suasana tersebut menjadikan pembelajaran yang tidak konduksif dan tidak efektif sehingga materi yang tersampaikan tidak dapat diterima dan dipahami peserta didik secara optimal. Guru perlu menyadari bahwa pada saat mengajar, guru lebih memposisikan dirinya sebagai fasilitator. Keaktifan peserta didik dalam menjalani proses belajar mengajar merupakan salah satu kunci keberhasilan pencapaian tujuan pendidikan. Oleh karena itu penelitian bertujuan untuk mengetahui: 1) Peningkatan hasil belajar peserta didik yang menggunakan model pembelajaran think pairs share (TPS) pada kelas eksperimen sebelum pengukuran awal (pretest) dan sesudah pengukuran akhir (posttest) di SMK Hepweti Ciamis. 2) Peningkatan hasil belajar peserta didik yang menggunakan metode Visualization, Auditory, Kinestetic (VAK) pada kelas eksperimen sebelum pengukuran awal (pretest) dan sesudah pengukuran akhir (posttest) di SMK Hepweti Ciamis. 3) Perbedaan peningkatan hasil belajar peserta didik yang menggunakan model pembelajaran think pairs share (TPS) lebih tinggi dibanding dengan hasil belajar peserta didik yang menggunakan model Visualization, Auditory, Kinestetic (VAK) pada pengukuran akhir (posttest). Metode penelitian yang digunakan dalam penelitian ini adalah Pre Exprerimental Desgn. Teknik pengumpulan data dilakukan melalui Pretest dan Posttest. Teknik analisis data melalui perhitungan N-Gain, Uji t dan Uji F. Pengujian hipotesis digunakan dengan rumus $t$-test. Berdasarkan kajian teori dan analisis data yang telah peneliti paparkan diatas, maka dapat disimpulkan sebagai berikut: 1) Terdapat peningkatan yang signifikan tingkat hasil belajar peserta didik yang menggunakan model pembelajaran Think Pairs Share pada mata pelajaran Akuntansi Biaya di kelas XI Akuntansi 1 melalui pengukuran awal (pretest) sebesar 53,26, pengukuran akhir (posttest) sebesar 91,74 denga N-Gain 0,8 dengan kategori tinggi. 2) Terdapat peningkatan yang signifikan tingkat hasil belajar peserta didik yang menggunakan model pembelajaran Visualization, Auditory, Kinesthetic pada mata pelajaran Akuntansi Biaya di kelas XI Akuntansi 1 melalui pengukuran awal (pretest) sebesar 42,08, pengukuran akhir (posttest) sebesar 79,20 dengan N-Gain 0,6 dengan kategori sedang. 3) Terdapat perbedaan peningkatan yang signifikan dari hasil belajar peserta didik yang menggunakan model pembelajaran Think Pairs Share lebih tinggi dibandikan dengan hasil belajar peserta didik yang menggunakan model pembelajaran Visualization, Auditory, Kinesthetic pada pengukuran akhir (posttest) kelas XI AK 1 dan pada pengukuran akhir (posttest) kelas XI AK 2 (hasil uji t-test diperoleh $t_{\text {hitung }}>t_{\text {tabel }}$ yaitu 8,59 $>2,02$ dengan taraf signifikan 5\% dan derajat kebebasan(dk) 45 Ha: Diterima.
\end{abstract}

Kata Kunci: Hasil belajar; Think Pairs Share; Visualization, Auditory, Kinesthetic; Akuntansi Biaya 


\section{PENDAHULUAN}

Pembelajaran adalah suatu proses untuk menyampaikan materi secara formal kepada pesrta didik, selain itu dalam pembelajaran guru harus dapat menciptakan berbagai interaksi dengan peserta didik. Selama ini pembelajaran dikelas selalu berpusat pada guru yang menerangkan dan peserta didik mendengarkan. Suasana tersebut menjadikan pembelajaran yang tidak konduksif dan tidak efektif sehingga materi yang tersampaikan tidak dapat diterima dan dipahami peserta didik secara optimal. Guru perlu menyadari bahwa pada saat mengajar, guru lebih memposisikan dirinya sebagai fasilitator. Keaktifan peserta didik dalam menjalani proses belajar mengajar merupakan salah satu kunci keberhasilan pencapaian tujuan pendidikan. Menurut Didi Supriadie (2012: 127) "Pembelajaran adalah suatu konsepsi dari dua dimensi kegiatan belajar dan mengajar yang searah, yakni diarahkan pada pencapaian tujuan (penguasaan sejumlah kompetensi)". Sedangkan menurut Gagne, Briggs, dan Wager (dalam Rusmono 2012:6) "Pembelajaran adalah serangkaian kegiatan yang dirancang untuk memungkinkan terjadinya proses pembelajaran pada peserta didik".

Berdasarkan pengamatan, pada umumnya guru hanya menyajikan pembelajaran secara teoritis serta cenderung mentransferkan ilmu dengan proses belajar mengajar yang pasif tanpa memperhatikan ketrampilan berpikir peserta didik dan tanpa melatih peserta didik untuk berpikir kritis. Proses pembelajaran semacam ini mengakibatkan suatu proses belajar mengajar yang tidak banyak melibatkan peserta didik untuk berinteraksi didalamnya, sehingga waktu tersita dengan penyampaian materi yang secara monoton tanpa menggunakan media pembelajaran maupun strategi pembelajaran.

Selama ini pelajaran Akuntansi identik dengan pelajaran yang banyak menghitung, maka dalam proses belajar mengajar harus menggunakan metode maupun strategi pembelajaran yang bervariasi. dengan adanya strategi pembelajaran yang bervariasi menimbulkan keaktifan peserta didik dalam proses pembelajaran dan dapat merangsang serta mengembangkan bakat peserta didik, agar peserta didik mampu berpikir secara kritis dan dapat memecahkan permasalahan-permasalahan dalam kehidupannya.

Dari data pada awal penelitian dapat diperoleh informasi hasil belajar yang masih sangat rendah. Hal ini merupakan sebuah permasalahan yang sangat serius dan perlu dicarikan solusinya. Dan jika dibiarkan saja tentunya akan sangat merugikan semua pihak, siswa selaku subjek belajar, guru dan sekolah kerena tujuan proses pendidikan ini tidak tercapai.

Berdasarkan observasi lapangan diperoleh rata-rata nilai mata pelajarannilai UAS mata pelajaran akuntansi sangat jelas sekali bahwa nilai UAS kelas XI AK 1 nilai rata-ratanya yaitu 79,88 dan sudah memenuhi Kriteria Ketuntasan Minimum (KKM) yang telah ditentukan oleh guru mata pelajaran akuntansi yaitu 78. Nilai tertinggi di kelas XI AK 1 yaitu 85 dan nilai teredahnya 68 yang sangat jauh dari nilai KKM yang telah ditentukan. Untuk jumlah peserta didik yang belum memenuhi KKM sebanyak 6 orang dari jumlah peserta didik 26 di kelas XI AK1.

Untuk kelas XI AK 2 nilai rata-rata yang di dapat adalah 78,44 dan sudah memenuhi KKM yang diharapkan. Untuk kelas XI AK 2 nilai tertinggi 86 dan nilai terendah 68 tidak sesuai dengan nilai KKM yang telah ditentukan. Untuk kelas XI AK 2 jumlah peserta didik yang belum memenuhi KKM sebanyak 8 orang.

Untuk meningkatkan hasil belajar peserta didik, model pembelajaran merupakan salah satu komponen agar tujuan pendidikan dapat tercapai. Banyak model pembelajaran yang dipelajari, namun pada kesempatan ini peneliti mencoba menggunakan model pembelajaran kooperatif tipe think pair share dan model pembelajaran visualization, auditory, kinesthetic (VAK).

Menurut Miftahul Huda (2015:206) “

Think Pairs Share merupakan strategi memperkenalkan gagasan tentang waktu 'tunggu atau berfikir' (wait or thnk time) pada elemen interaksi pembelajaran kooperatif yang saat ini menjadi salah satu faktor ampuh dalam meningkatkan respon siswa terhadap pertanyaan".

Model pembelajaran think pair share merupakan model pembelajaran memberi peserta didik waktu untuk berfikir dan merespon serta saling bantu satu sama lain. Model ini memperkenalkan ide "waktu berfikir atau waktu tunggu" yang menjadi factor kuat dalam meningkatkan kemampuan peserta didik dalam merespon pertanyaan. Pembelajaran ini relative lebih sederhana karena tidak menyita waktu yang lama untuk mengatur tempat duduk ataupun mengelompokan peserta didik. Pembelajaran ini melatih peserta didik untuk 
berpendapat dan menghargai pendapat teman. Model ini memiliki prosedur yang secara eksplisit memberi peserta didik waktu untuk berfikir, menjawab, saling membantu satu sama lain. Dengan demikian, diharapkan peserta didik mampu bekerja sama, saling membutuhkan, dan saling bergantung pada kelompok kecil secara kooperatif.

Sedangkan model pembelajaran visualization, auditory, kinesthetic (VAK) merupakan model pembelajaran yang mengoptimalkan ketiga modalitas belajar tersebut untuk menjadikan si belajar merasa nyaman. Model VAK merupakan anak model dari model pembelajaran Quantum yang berprinsipuntuk menjadikan situasi belajar menjadi lebih nyaman dan menjanjikan bagi pembejarnya di masa depan.

Menurut Miftahul Huda (2015: 287) dalam Visualization, Auditory, Kinestetic (VAK: 1. Visual

Modalitas visual mengakses citra visual yang diciptakan maupun diingat, seperti warna, hubungan ruang, potert mental, dan gambar. Seorang peserta didik yang sangat mungkn memilik ciri-ciri berikut ini:

a) Teratur, memperhatikan segala sesuatu dan menjaga penampilan

b) Mengingat dengan gambar, lebih suka membaca daripada dibacakan

c) Membutuhkan gambaran dan tujuan menyeluruh untuk bisa menangkap detail atau mengingat apa yang dilihat.

\section{Auditoris}

Modalitas ini mengakses segala bunyi dan kata yang diciptakan maupun diingat, seperti music, nada, irama, rima, dialog internal, dan suara. Seorang peserta didik yang sangat auditoris dapat dicirikan sebagai berikut:

a) Perhatiannya mudah terpecah

b) Berbicara dengan pola berirama

c) Belajar dengan cara mendengarkan

d) Berdialog secara internal dan eksternal

\section{Kinestetik}

Modalitas ini mengakses segala jens gerak dan emosi yang diciptakan maupun diingat, seperti gerakan, kordinasi, irama, tanggapan emosional, dan kenyamanan fisik. Seorang peserta didik yang cenderung kinestetik dapat dicirikan sebagai berikut:

a) Menyentuh orang dan berdiri berdekatan, banyak gerak

b) Belajar sambil bekerja, menunjukan tulisan saat membaca, menanggapi secara fisik

Mengingat sambil berjalan dan melihat.

\section{METODE PENELITIAN}

Metode yang digunakan untuk meneliti masalah yang telah dikemukakan di atas yaitu menggunakan metode eksperimen. Metode penelitian yang digunakan dalam penelitian ini dalah pre exprerimental desgn. Menurut Arikunto, Suharsimi (2010: 123) "Pre exprerimental desgn seringkali dipandang sebagai eksperimen yang tidak sebenarnya. Oleh karena itu sering disebut juga dengan istilah "quasi experiment" atau eksperimen pura-pura. Disebut demikian karena eksperimen jenis ini belum memnuhi persyaratan seperti cara eksperimen yang dapat dikatakan ilmiah mengikuti peraturan-peraturan tertentu".

Dalam penelitian ini objek yang digunakan adalah manusia dengan subjek penelitian yang telah ditentukan jenisnya yaitu mengujicobakan penggunaan model pembelajaran kooperatif tipe Think Pair Share dan Visualization, Auditory, Kinesthetic

\section{HASIL PENELITIAN DAN PEMBAHASAN}

Adapun data rekapitulasi hasil belajar peserta didik berdasarkan pengukuran awal (pretest) dan pengukuran akhir (posttest) pada kelas Eksperimen I adalah sebagai berikut:

Tabel 1

Data Hasil Belajar Peserta didik Kelas Eksperimen I

\begin{tabular}{ccc} 
Keterangan & Pretest & Posttest \\
\hline Jumlah Sampel & 26 & 26 \\
Nilai tertinggi & 65 & 100 \\
Nilai Terendah & 40 & 80 \\
Nilai Rata-rata & 53,85 & 91,15 \\
Modus & 60 & 95
\end{tabular}

Sumber: data diolah oleh peneliti tahun 2016 
Berdasarkan Tabel 1 di atas diperoleh data hasil belajar peserta didik pada saat pengukuran awal (pretest) di kelas eksperimen I dengan jumlah sampel 26 peserta didik yaitu nilai tertinggi 65 dan nilai terendah 40. Nilai rata-rata yang diperoleh sebesar 53,85 dan modus sebesar 60. Sedangkan setelah diberikan perlakuan dengan menggunakan model pembelajaran Think Pairs Share dengan jumlah sampel 26 peserta didik diperoleh nilai tertinggi sebesar 100 dan nilai terendah sebesar 80 . Nilai ratarata yang diperoleh sebesar 91,15 dan modus (nilai yang sering muncul) sebesar 95 .

Adapun data hasil belajar peserta didik pada pengukuran awal (pretest) dan pengukuran akhir (posttest) pada kelas Eksperimen 2 adalah sebagai berikut:

Tabel 2

Data Hasil Belajar Peserta didik Kelas Eksperimen 2

\begin{tabular}{ccc} 
Keterangan & Pretest & Posttest \\
\hline Jumlah Sampel & 24 & 24 \\
Nilai tertinggi & 70 & 85 \\
Nilai Terendah & 30 & 75 \\
Nilai Rata-rata & 42,08 & 79,2 \\
Modus & 45 & 80
\end{tabular}

Sumber: data diolah oleh peneliti tahun 2016

Berdasarkan tabel 2 di atas diperoleh data hasil belajar peserta didik pada saat pengukuran awal (pretest) di kelas Eksperimen 2 dengan jumlah sampel 24 peserta didik yaitu nilai tertinggi 70 dan nilai terendah 30. Nilai rata-rata yang diperoleh sebesar 42,08 dan modus sebesar 45. Sedangkan setelah diberikan perlakuan dengan menggunakan model pembelajaran Visualzation, auditory, Kinesthetic dengan jumlah sampel 24 peserta didik diperoleh nilai tertinggi sebesar 85 dan nilai terendah sebesar 75. Nilai rata-rata yang diperoleh sebesar 79,2 dan modus (nilai yang sering muncul) sebesar 80 .

Untuk mengetahui perbedaan hasil belajar peserta didik yang menggunakan Model Pembelajaran Think Pairs Share dengan peserta didik yang menggunakan Model pembelajaran Visualization, Auditory, Kinesthetic yaitu dengan menggunakan uji t-test. Adapun hasil perhitungan uji t-tes, dapat diketahui dari tabel berikut :

Tabel 3

Hasil perhitungan t-tesUji dua pihak

\begin{tabular}{|c|c|c|c|c|c|c|c|c|c|c|c|c|}
\hline Kelas & $\begin{array}{l}\text { Standa } \\
\mathrm{r} \\
\text { deviasi }\end{array}$ & $X_{1}$ & $X_{2}$ & $\begin{array}{l}X_{1} \\
1\end{array}$ & $\begin{array}{l}\mathrm{X}_{2} \\
1\end{array}$ & ${ }_{2}\left(\mathrm{X}_{1}{ }^{\prime}\right)$ & $\left(\mathrm{X}_{2}^{\prime}\right)$ & $\begin{array}{l}\mathrm{D} \\
\mathrm{k}\end{array}$ & A & $\begin{array}{l}\mathrm{t}_{\text {hitun }} \\
\mathrm{g}\end{array}$ & $\mathrm{t}_{\text {tabel }}$ & $\begin{array}{l}\text { Hasil } \\
\text { hipotesis }\end{array}$ \\
\hline $\begin{array}{l}\text { Eksperime } \\
\text { n } 1\end{array}$ & 6,09 & 91,1 & 79, & & & 37,1 & 13,1 & & 0,0 & & 2,0 & $\begin{array}{l}\text { Ha: } \\
\text { diterima }\end{array}$ \\
\hline $\begin{array}{l}\text { Eksperime } \\
\text { n } 2\end{array}$ & 3,63 & 5 & 2 & 0 & 0 & 3 & 8 & 48 & 5 & & 1 & $\begin{array}{l}\text { Ho:ditola } \\
\mathrm{k}\end{array}$ \\
\hline
\end{tabular}

Berdasarkan tabel tersebut, maka dapat diketahui bahwa $t_{\text {hitung }}>t_{\text {tabel }}(8,48>2,01)$. Hal tersebut menunjukan bahwa hipotesis diterima, artinya terdapat perbedaan yang signifikan antara hasil belajar peserta didik yang menggunakan model pembelajaran Think Pairs Share dengan hasil belajar peserta yang menggunakan model pembelajaran Visualization, Audtory, Kinesthetic. Hal ini dilihat dari standar deviasi untuk kelas eksperimen 1 sebesar 6,09 sedangkan kelas eksperimen 2 sebesar 3,63. Rata-rata nilai posttest kelas eksperimen 1 (XI Akuntansi 1) yaitu sebesar 91,15 sedangkan kelas eksperimen 2 (XI Akuntansi 2) sebesar 79,2. Dan hasil pengukuran antara $X_{1}-X$ secara keseluruhan berjumlah 0 serta untuk pengukuran antara $X_{2}$. $\mathrm{X}$ secara keseluruhan juga berjumlah 0 . Dan untuk hasil pengkuadratan $\left(\mathrm{X}_{1}\right)^{2}$ berjumlah 37,13 sedangkan untuk hasil pengkuadratan 
$\left(\mathrm{X}_{2}^{\prime}\right)^{2}$ berjumlah 13,18. Selanjutnya untuk derajat kebebasan (dk) 48 dengan taraf kepercayaan $(\alpha)$ 5\% dan thitung sebesar 8,48 sedangkan $t_{\text {tabel }}$ sebesar 2,01. dengan demikian $\mathrm{t}_{\text {hitung }}>\mathrm{t}_{\text {tabel }}(8,48>2,01)$ artinya hipotesis diterima (Ha:diterima dan Ho:ditolak).

Menurut Miftahul Huda (2015:206) "Think Pairs Share merupakan strategi memperkenalkan gagasan tentang waktu 'tunggu atau berfikir' (wait or think time) pada elemen interaksi pembelajaran kooperatif yang saat ini menjadi salah satu faktor ampuh dalam meningkatkan respon siswa terhadap pertanyaan".

Model pembelajaran Think Pairs Share sangat menekankan untuk mampu berkomunikasi dengan siswa lain yakni teman sekelompoknya, karena disana ada proses wawancara pada teman sekelompoknya serta pada cara tiap siswa menyampaikan hasil diskusi didepan kelompok yang lain, sebab setiap anak memiliki kesempatan untuk menyampaikan pendapat setiap kelompoknya. Kelompok ini biasanya hanya terdiri dari 2 orang saja.

Menurut Miftahul Huda (2015:287) dalam Visualization, Auditory, Kinestetic (VAK): a. Visual

Modalitas visual mengakses citra visual yang diciptakan maupun diingat, seperti warna, hubungan ruang, potert mental, dan gambar

b. Auditoris

Modalitas ini mengakses segala bunyi dan kata yang diciptakan maupun diingat, seperti music, nada, irama, rima, dialog internal, dan suara.

c. Kinestetik

Modalitas ini mengakses segala jens gerak dan emosi yang diciptakan maupun diingat, seperti gerakan, kordinasi, irama, tanggapan emosional, dan kenyamanan fisik

Berdasarkan pengertian yang telah diungkapkan diatas antara satu dengan yang lainnya memiliki maksud yang sama, yaitu terjadi kesepakatan antara siswa dengan guru dan siswa dengan siswa untuk berkolaborasi memecahkan suatu masalah dalam pembelajaran dengan cara-cara yang kolaboratif seperti halnya menyelesaikan masalah yang terjadi dalam kehidupan sosial siswa.

Berdasarkan hasil penelitian dapat diketahui bahwa hasil belajar peserta didik yang menggunakan model pembelajaran Think Pairs Share pada kelas eksperimen 1 (XI Akuntansi 1) memiliki nilai rata-rata posttest lebih tinggi dibandingkan dengan hasil belajar peserta didik yang menggunakan model pembelajaran Visualization, Auditory, Kinesthetic pada kelas eksperimen 2 (XI Akuntansi 2). Model pembelajaran Think Pairs Share lebih baik diterapkan pada mata pelajaran Akuntansi Biaya pada kompetensi dasar menyusun laporan biaya dibandingkan dengan model pembelajaran Visualization, Auditory, Kinesthetic.

Berdasarkan pengujian hipotesis, yang menyatakan bahwa terdapat perbedaan hasil belajar peserta didik yang menggunakan model pembelajaran Think Pairs Share dengan hasil belajar peserta didik yang menggunakan model pembelajaran Visualization, Auditory, Kinesthetic pada mata pelajaran akuntansi biaya kelas XI Akuntansi SMK HEPWETI Ciamis.

Dengan demikian model pembelajaran Think Pairs Share dengan model pembelajaran Visualization, Auditory, Kinesthetic memiliki peran yang positif dalam meningkatkan hasil belajar peserta didik, tetapi hasil belajar peserta didik yang menggunakan model pembelajaran Think Pairs Share lebih tinggi dibandingkan dengan penggunaan model pembelajaran Visualization, Auditory, Kinesthetic.

\section{SIMPULAN}

Berdasarkan hasil penelitian yang dilakukan, dapat ditarik simpulan sebagai berikut:

1. Terdapat peningkatan hasil belajar peserta didik yang menggunakan model pembelajaran Think Pairs Share pada mata pelajaran Akuntansi Biaya di kelas XI Akuntansi 1 melalui pengukuran awal (pretest) dan pengukuran akhir (posttest). Hal ini disebabkan peserta didik belum mempelajari materi yang akan diberikan dan dalam menyampaikan materinya guru hanya dengan menggunakan model ceramah. Setelah penerapan model pemelajaran Think Pairs Share mengalami peningkatan pengetahuan dibandingkan dengan pengukuran semula.

2. Terdapat peningkatan hasil belajar peserta didik yang menggunakan model pembelajaran Visualization, Auditory, Kinesthetic pada mata pelajaran Akuntansi Biaya di kelas XI Akuntansi 1 melalui pengukuran awal (pretest) dan pengukuran akhir (posttest). Dengan menerapkan model pembelajaran Visualization, Auditory, Kinesthetic mengalami peningkatan pengetahuan dibandingkan dengan pengukuran semula meskipun tidak lebih 
tinggi dengan perbedaan yang terjadi pada kegiatan pembelajaran yang mengguanakan model pembelajaran Think Pairs Share.

3. Terdapat perbedaan hasil belajar peserta didik yang menggunakan model pembelajaran Think Pairs Share lebih tinggi dibandikan dengan hasil belajar peserta didik yang menggunakan model pembelajaran Visualization, Auditory, Kinesthetic pada pengukuran akhir (posttest) kelas XI AK 1 dan pada pengukuran akhir (posttest) kelas XI AK 2.

\section{DAFTAR PUSTAKA}

Huda, Miftahul. 2015. Model-Model Pengajaran dan Pembelajaran. Yogyakarta: Pustaka Belajar

Suharsimi, Arikunto. (2010). Prosedur Penelitian Suatu Pendekatan Praktik.. Jakarta: PT Rineka Cipta.

Supriadie, Didi dan Darmawan Deni. 2013. Komunikasi Pembelajaran.Bandung: PT Remaja Posdakarya 